\title{
Women's sexuality as surveyed by the FSFI questionnaire in those with no history of childhood sexual abuse or violence
}

\author{
Mikołaj Sinica', Grażyna Jarząbek-Bielecka', Magdalena Pisarska-Krawczyk ${ }^{2,3}$, \\ Anna Potasińska-Sobkowska ${ }^{4}$, Maciej Wilczak ${ }^{2,4}$, Małgorzata Mizgier ${ }^{5}$, Witold Kędzia' \\ ${ }^{1}$ Clinic of Gynecology of Department of Perinatology and Gynecology, Division of Developmental Gynecology \\ and Sexuology of Department of Perinatology and Gynecology, University of Medical Sciences, Poznan, Poland \\ ${ }^{2}$ Higher Vocational State School in Kalisz, Poland \\ ${ }^{3}$ Department of Maternal and Child Health, University of Medical Sciences, Poznan, Poland \\ ${ }^{4}$ Department of Medical Education, University of Medical Sciences, Poznan, Poland \\ ${ }^{5}$ Division of Nutrition, Department of Hygiene and Human Nutrition, University of Life Sciences, Poznan, Poland
}

\begin{abstract}
The usefulness of the Female Sexual Functioning Index (FSFI) questionnaire is presented for investigating women's sexual functioning and their determinant factors. Subjects were 133 women who had never experienced any form of sexual abuse in their childhood or any types of violence; these adverse and significant factors were thus absent from the study. The FSFI was found to be an excellent tool in screening for any sexual disorders in women.
\end{abstract}

KEY WORDS: women's sexuality, FSFI questionnaire, sexual desire.

ADDRESS FOR CORRESPONDENCE: Grażyna Jarząbek-Bielecka, The Clinic of Gynaecology of the Department of Perinatology and Gynaecology, University of Medical Sciences, 5 C Rokietnicka Street, 60-806 Poznan, Poland, e-mail: grajarz@o2.pl

\section{INTRODUCTION}

On a global scale, it is estimated that on average one in 3-4 women have been victims of sexual abuse (25-33\%) and one in 6-10 men (10-16\%). According to the Child Protection Committee in Poland (KOPD in Polish), every fifth girl (around 20\%) and every fifteenth boy (around 5-6\%) below the age of 15 years has experienced sexual abuse $[1,2]$. Such acts of abuse give rise to adverse consequences in the later sexual life of adults. The consequences of such harassment/molestation include the following: aversion to sharing one's body with others, associating love with violence, no pleasure in being touched, an emotional blockade, being afraid of showing anger in a relationship, chronic fear, changes in tactile association, inability to fully relax, inability to "lose control" in any given situation as the world is perceived as being unsafe/hostile, depression, inability to trust others, sexual behaviour/contact is non-pleasurable, anxiety in forming deep emotional and sexual relationships, sexual dysfunction and loss of libido $[1,3]$. Because experiencing violence can also disrupt women's sexuality, our study aimed to investigate normal sexual function in women through using the FSFI questionnaire in those who have never experienced such occurrences or any forms of violence. The FSFI was adapted to Polish circumstances/conditions by members of the Polish Gynaecological Association: Dr. Krzysztof Nowosielski MD (Department of Gynaecology and Obstetrics at the Regional Specialist Hospital in Tychy) and Dr. Beata Wróbel MD (Sexual Medical Centre at Dąbrowa Górnicza ). The study supervisor was Professor of Medicine Richard Poreba.

A similar questionnaire, previously prepared by the International Society of Sexual Medicine, served as the 
basis of our study questionnaire. This consists of 19 closed questions inter alia addressing how often sex was desired and any difficulties experienced in achieving orgasm. The Polish FSFI version (IFSK) was made available to the medical community at the scientific conference entitled "Sexuality is the key to sexual and reproductive health in partners"; this IFSK conference was organised under the honorary patronage of the European Association for Health Promotion "PRO-SALUTEM". During the conference, our study authors familiarised doctors with the practical aspects of using the Polish questionnaire version for diagnosing sexual health problems and showing how it may be used by every woman. Indeed, the conference filled the gap in Polish scientific studies concerning gynaecological sexology, which in Poland still remains an undeveloped branch of medicine [4].

The aim of the study was to investigate women's sexuality in those never having suffered violence.

\section{MATERIAL AND METHODS}

Subjects were 133 women who had never experienced sexual abuse in their childhood or any forms of violence. Data for the following variables were obtained for each subject: age, body mass, height, menarche, use of hormonal drugs (e.g. hormone replacement therapy, contraceptives) and sexual initiation. Sexual functioning was investigated by the aforementioned FSFI questionnaire (Female Sexual Function Test) consisting of 21 questions. The first 19 concerned sexual activity engaged in within the last 4 weeks taking into account the following 6 domain-structured areas: desire (questions $1 \& 2$ ), arousal (questions 3-6), lubrication (questions 7-10), orgasm (questions 11-13), satisfaction (questions 14-16) and pain/discom-

TABLE 1. Descriptive statistics of age, BMI, menarche and sexual initiation in women subjects

\begin{tabular}{|l|c|c|c|c|c|c|}
\hline Variable & $n$ & Mean & SD & Median & Min. & Max. \\
\hline Age (years) & 133 & 28.2 & 10.3 & 24.0 & 18.0 & 63.0 \\
\hline BMI $\left(\mathrm{kg} / \mathrm{m}^{2}\right)$ & 133 & 22.4 & 3.5 & 21.5 & 16.7 & 34.0 \\
\hline $\begin{array}{l}\text { Menarche } \\
\text { (years) }\end{array}$ & 131 & 12.9 & 1.6 & 13.0 & 10.0 & 18.0 \\
\hline $\begin{array}{l}\text { Sexual } \\
\text { initiation } \\
\text { (years) }\end{array}$ & 123 & 18.5 & 2.4 & 18.0 & 13.0 & 28.0 \\
\hline
\end{tabular}

TABLE 2. Women's various replies to "What hormonal drugs do you take?"

\begin{tabular}{|l|c|c|}
\hline $\begin{array}{l}\text { What hormonal drugs } \\
\text { are taken }\end{array}$ & Number & Percentage \\
\hline No & 78 & 58.6 \\
\hline Contraceptive pills & 48 & 36.1 \\
\hline Other hormonal drugs & 15 & 11.3 \\
\hline Total & 141 & 106.0 \\
\hline
\end{tabular}

fort (questions 17-19). The questions were numerically graded by scores (domain scoring), in total, on a scale from 2.0 to 36.0. The last two questions were on fulfilling women's sex-drive needs (questions $20 \& 21$ ).

Numerical variables were described by their means, standard deviations (SD) and medians with maximum and minimum ranges. Because the data were non-normally distributed, a non-parametric test on the significance of differences between two independent groups was adopted: the Mann-Whitney $U$ test. Associations between numerical variables were assessed by Spearman rank correlation. The statistical analyses were performed using the Statistica 10PL programme. Statistical significance was adopted as being $p<0.05$.

\section{RESULTS AND DISCUSSION}

AGE, BMI, MENARCHE AND SEXUAL INITIATION

Women's age ranged from 18 to 63 years, with a mean of $28.2 \pm 10.3$ and a median of 24 years. There were 122 subjects below 45 years of age, but only 11 who were above this age; this small number thus precluded any reliable comparison of the $>45$ year age group with those below this age.

The BMI varied from 16.73 to $33.98 \mathrm{~kg} / \mathrm{m}^{2}$, the mean BMI being $22.43 \pm 3.53 \mathrm{~kg} / \mathrm{m}^{2}$ and median $21.47 \mathrm{~kg} / \mathrm{m}^{2}$. The number of women who were underweight or had normal body mass was 102, with 31 women being either overweight or obese.

On average, menarche occurred at $12.9 \pm 1.612$ years, ranging from 10 to 18 years age. Two women could not remember when they had their menarche. In all subjects, menarche had occurred spontaneously.

The first sexual contacts made by the subjects occurred, on average, at age $18.5 \pm 2.4$ years (sexual initiation ranging between 13 and 28 years), with ten women not providing their age when this happened (not having had their first sexual contacts).

\section{HORMONAL DRUGS}

There were 78 subjects (58.6\%) who never took hormonal drugs, with the remainder ( 55 subjects) doing so. Of these, 48 took contraceptives (36.1\%) and 14 (11.3\%) took other hormonal drugs.

\section{FSFI QUESTIONNAIRE}

From the 133 subjects, 15 replied that they had had no sexual intercourse in the last 4 weeks, including:

- 9 women reporting not being sexually active in the last 4 weeks,

- 4 women replying that they were sexually active but that they did not have intercourse in the last 4 weeks,

- 2 women replying that they were active sexually within the last 4 weeks,

- 3 women saying that they were sexually active, they did not have intercourse and that they attempted intercourse within the last 4 weeks. 
The overall FSFI scores in subjects ranged from 2.0 to 36 points with a mean of $25.8 \pm 8.5$ and median of 28.5 points. The highest average FSFI score was observed in the satisfaction domain at $4.7 \pm 1.5$, range 0.8 to 6.0 , whereas the lowest scoring was for the desire domain: mean $3.9 \pm 1.3$, range 1.2 to 6.0 .

\section{CORRELATIONS OF AGE, MENARCHE, BMI AND SEXUAL INITIATION WITH FSFI SCORES}

Significant correlations between age, BMI, menarche and sexual initiation with FSFI scores were found in the following:

- age and desire; medium negative correlation $(r=-0.42)$; desire decreases with age,

- age and arousal; weak negative correlation $(r=-0.32)$; arousal decreases with age,

- age and lubrication; weak negative correlation $(r=-0.24)$; lubrication decreases with age,

- age and orgasm; weak negative correlation $(r=-0.22)$; orgasm decreases with age,

- age and overall FSFI score; weak negative correlation $(r=-0.24)$; overall FSFI score decreases with age,

- BMI and desire; weak negative correlation $(r=-0.20)$; with increasing BMI desire diminishes,

- BMI and arousal; weak negative correlation $(r=-0.20)$; with increasing BMI arousal diminishes,

- BMI and satisfaction; weak negative correlation $(r=-0.17)$; with increasing BMI satisfaction diminishes,

- menarche and desire; weak negative correlation $(r=-0.29)$; with later occurring menarche, desire diminishes,

- menarche and arousal; weak negative correlation $(r=-0.28)$; with later occurring menarche, arousal diminishes,

- menarche and lubrication; weak negative correlation ( $r=-0.18)$; with later occurring menarche, lubrication diminishes,

- menarche and orgasm; weak negative correlation $(r=-0.22)$; with later occurring menarche, orgasm diminishes,

- sexual initiation and desire; weak negative correlation $(r=-0.20)$; with later sexual initiation, desire diminishes,

- sexual initiation and orgasm; weak negative correlation $(r=-0.18)$; with later sexual initiation, orgasm diminishes.

All other correlations between variables and domains were statistically insignificant.

\section{FSFI SCORES AND WOMEN'S BMI}

Subjects were divided into two groups according to their BMI:

- $<25$; underweight and normal BMI women, $n=102$,

- $\geq 25$; overweight and obese women, $n=31$.

Mean FSFI scores for all domains and overall FSFI were higher in women who were underweight or had
TABLE 3. Descriptive statistics for FSFI scored replies for women subjects

\begin{tabular}{|l|c|c|c|c|c|c|}
\hline $\begin{array}{l}\text { FSFI } \\
\text { domain }\end{array}$ & $n$ & Mean & SD & Median & Min. & Max. \\
\hline $\begin{array}{l}\text { Desire } \\
\text { (score) }\end{array}$ & 133 & 3.9 & 1.3 & 3.6 & 1.2 & 6.0 \\
\hline $\begin{array}{l}\text { Arousal } \\
\text { (score) }\end{array}$ & 133 & 4.2 & 1.6 & 4.8 & 0.0 & 6.0 \\
\hline $\begin{array}{l}\text { Lubrication } \\
\text { (score) }\end{array}$ & 133 & 4.4 & 1.8 & 5.1 & 0.0 & 6.0 \\
\hline $\begin{array}{l}\text { Orgasm } \\
\text { (score) }\end{array}$ & 133 & 4.1 & 1.8 & 4.8 & 0.0 & 6.0 \\
\hline $\begin{array}{l}\text { Satisfaction } \\
\text { (score) }\end{array}$ & 133 & 4.7 & 1.5 & 5.2 & 0.8 & 6.0 \\
\hline Pain (score) & 133 & 4.4 & 1.9 & 5.2 & 0.0 & 6.0 \\
\hline $\begin{array}{l}\text { Total FSFI } \\
\text { (score) }\end{array}$ & 133 & 25.8 & 8.5 & 28.5 & 2.0 & 36.0 \\
\hline
\end{tabular}

TABLE 4. Spearman rank correlations for women subjects

\begin{tabular}{|l|c|c|c|c|}
\hline Variable & Age & BMI & Menarche & $\begin{array}{c}\text { Sexual } \\
\text { initiation }\end{array}$ \\
\hline Desire & $-0.42^{*}$ & $-0.20^{*}$ & $-0.29^{*}$ & $-0.20^{*}$ \\
\hline Arousal & $-0.32^{*}$ & $-0.20^{*}$ & $-0.28^{*}$ & -0.16 \\
\hline Lubrication & $-0.24^{*}$ & -0.12 & $-0.18^{*}$ & -0.14 \\
\hline Orgasm & $-0.22^{*}$ & -0.09 & $-0.22^{*}$ & $-0.18^{*}$ \\
\hline Satisfaction & -0.16 & $-0.17^{*}$ & -0.15 & -0.11 \\
\hline Pain & -0.04 & 0.03 & -0.13 & -0.10 \\
\hline Total FSFI & $-0.24^{*}$ & -0.13 & $-0.24^{*}$ & -0.17 \\
\hline
\end{tabular}

*Statistical significance; $p<0.05$

a normal BMI compared to those who were overweight or obese. Median FSFI for the domains of arousal, lubrication, satisfaction, pain and overall FSFI were higher in subjects who were underweight or those with normal BMI when compared to overweight and obese subjects. Medians for the domains of desire and orgasm were the same in both previously defined BMI groups (i.e., below or above a BMI of 25). Upon comparing FSFI scores in these two BMI groups, no significant differences were found in any of the domains or overall FSFI $(p>0.05)$.

\section{FSFI SCORES AND TAKING HORMONAL DRUGS}

Both means and medians of FSFI scores for almost all the domains (excepting satisfaction) along with overall FSFI scores are higher in women taking hormonal drugs than in those not taking them, the mean and median for the satisfaction domain being the same. Upon comparing subjects taking or not taking hormonal drugs, the following differences between domains were found to be significant: 
TABLE 5. Descriptive statistics of FSFI score differences assessed by the Mann-Whitney U test between the two defined BMI groupings

\begin{tabular}{|c|c|c|c|c|c|c|c|}
\hline \multirow[t]{2}{*}{ FSFI domain } & \multirow[t]{2}{*}{ BMI } & \multirow[t]{2}{*}{$n$} & \multirow[t]{2}{*}{ Mean } & \multirow[t]{2}{*}{ SD } & \multirow[t]{2}{*}{ Median } & \multicolumn{2}{|c|}{ Mann-Whitney $U$ test } \\
\hline & & & & & & Corrected & $p$ \\
\hline \multirow[t]{2}{*}{ Desire (score) } & $<25$ & 102 & 4.0 & 1.3 & 3.6 & \multirow[t]{2}{*}{1.236} & \multirow[t]{2}{*}{0.216} \\
\hline & $\geq 25$ & 31 & 3.6 & 1.5 & 3.6 & & \\
\hline \multirow[t]{2}{*}{ Arousal (score) } & $<25$ & 102 & 4.4 & 1.5 & 4.8 & \multirow[t]{2}{*}{1.335} & \multirow[t]{2}{*}{0.182} \\
\hline & $\geq 25$ & 31 & 3.8 & 1.9 & 4.5 & & \\
\hline \multirow[t]{2}{*}{ Lubrication (score) } & $<25$ & 102 & 4.6 & 1.6 & 5.1 & \multirow[t]{2}{*}{1.061} & \multirow[t]{2}{*}{0.289} \\
\hline & $\geq 25$ & 31 & 4.0 & 2.2 & 4.8 & & \\
\hline \multirow[t]{2}{*}{ Orgasm (score) } & $<25$ & 102 & 4.2 & 1.7 & 4.8 & \multirow[t]{2}{*}{0.301} & \multirow[t]{2}{*}{0.764} \\
\hline & $\geq 25$ & 31 & 3.9 & 2.1 & 4.8 & & \\
\hline \multirow[t]{2}{*}{ Satisfaction (score) } & $<25$ & 102 & 4.8 & 1.4 & 5.2 & \multirow[t]{2}{*}{0.319} & \multirow[t]{2}{*}{0.749} \\
\hline & $\geq 25$ & 31 & 4.4 & 1.8 & 4.8 & & \\
\hline \multirow[t]{2}{*}{ Pain (score) } & $<25$ & 102 & 4.5 & 1.8 & 5.2 & \multirow[t]{2}{*}{0.284} & \multirow[t]{2}{*}{0.776} \\
\hline & $\geq 25$ & 31 & 4.2 & 2.2 & 4.8 & & \\
\hline \multirow[t]{2}{*}{ Total FSFI (score) } & $<25$ & 102 & 26.4 & 7.7 & 28.8 & \multirow[t]{2}{*}{0.785} & \multirow[t]{2}{*}{0.432} \\
\hline & $\geq 25$ & 31 & 23.9 & 10.5 & 28.2 & & \\
\hline
\end{tabular}

TABLE 6. Descriptive statistics and Mann-Whitney U test FSFI outcomes for women subjects taking or not taking hormonal drugs

\begin{tabular}{|c|c|c|c|c|c|c|}
\hline \multirow[t]{2}{*}{ FSFI } & \multirow[t]{2}{*}{$\begin{array}{c}\text { Hormonal drugs } \\
\text { taken }\end{array}$} & \multirow[t]{2}{*}{$n$} & \multirow[t]{2}{*}{ Mean } & \multirow[t]{2}{*}{ SD } & \multirow[t]{2}{*}{ Median } & $\begin{array}{c}\text { Mann-Whitney } \\
\text { U test }\end{array}$ \\
\hline & & & & & & Corrected \\
\hline \multirow[t]{2}{*}{ Desire (score) } & Yes & 55 & 4.2 & 1.3 & 4.2 & \multirow[t]{2}{*}{2.034} \\
\hline & No & 78 & 3.7 & 1.3 & 3.6 & \\
\hline \multirow[t]{2}{*}{ Arousal (score) } & Yes & 55 & 4.5 & 1.4 & 4.8 & \multirow[t]{2}{*}{1.522} \\
\hline & No & 78 & 4.0 & 1.7 & 4.5 & \\
\hline \multirow[t]{2}{*}{ Lubrication (score) } & Yes & 55 & 4.8 & 1.5 & 5.1 & \multirow[t]{2}{*}{2.106} \\
\hline & No & 78 & 4.2 & 1.9 & 4.8 & \\
\hline \multirow[t]{2}{*}{ Orgasm (score) } & Yes & 55 & 4.5 & 1.6 & 5.2 & \multirow[t]{2}{*}{2.387} \\
\hline & No & 78 & 3.9 & 1.8 & 4.8 & \\
\hline \multirow[t]{2}{*}{ Satisfaction (score) } & Yes & 55 & 4.7 & 1.5 & 5.2 & \multirow[t]{2}{*}{0.128} \\
\hline & No & 78 & 4.7 & 1.5 & 5.2 & \\
\hline \multirow[t]{2}{*}{ Pain (score) } & Yes & 55 & 4.7 & 1.6 & 4.8 & \multirow[t]{2}{*}{0.567} \\
\hline & No & 78 & 4.3 & 2.1 & 5.2 & \\
\hline \multirow[t]{2}{*}{ Total FSFI (score) } & Yes & 55 & 27.3 & 7.5 & 29.0 & \multirow[t]{2}{*}{1.615} \\
\hline & No & 78 & 24.8 & 9.0 & 27.9 & \\
\hline
\end{tabular}

*Statistical significance; $p<0.05$

- desire; higher scores obtained by those taking hormonal drugs,

- lubrication; higher scores obtained by those taking hormonal drugs,

- orgasm; higher scores obtained by those taking hormonal drugs.

\section{SATISFACTION OF SEX DRIVE}

The majority of women either felt a moderate or strong urge to satisfy their sex drive at respectively $39.1 \%$ and $31.6 \%$. The fewest were those who felt this need to be weak at $1.5 \%$, whereas in $7.5 \%$ of women this need was declared absent. 


\section{CORRELATION BETWEEN FSFI SCORE AND THE NEED TO SATISFY THE SEX DRIVE}

Significant correlations between FSFI scores and the need to satisfy the sex drive were found in the following domains:

- desire; high positive correlation $(r=0.76)$; women achieving higher scores in this domain had stronger needs to satisfy their sex drives,

- arousal; moderate positive correlation $(r=0.44)$; women achieving higher scores in this domain had stronger needs to satisfy their sex drives,

- lubrication; moderate positive correlation $(r=0.39)$; women achieving higher scores in this domain had stronger needs to satisfy their sex drives,

- orgasm; moderate positive correlation $(r=0.34)$; women achieving higher scores in this domain had stronger needs to satisfy their sex drives,

- satisfaction; weak positive correlation $(r=0.28)$; Women achieving higher scores in this domain had stronger needs to satisfy their sex drives,

- pain; weak positive correlation $(r=0.29)$; women achieving higher scores in this domain had stronger needs to satisfy their sex drives,

- total FSFI; moderate positive correlation $(r=0.52)$; women achieving high scores in this domain had stronger needs to satisfy their sex drives.

\section{FULFILLING THE SATISFACTION OF THE SEX DRIVE}

All subjects answered questions on fulfilling their satisfaction of the sex drive. In all, 174 replies were received. Most women satisfied this need by having sexual intercourse with a man at $72.2 \%$, whereas $29.3 \%$ do so by masturbating and $9 \%$ through watching erotic movies or reading erotic books. It was found that $17.3 \%$ of women did all of these aforementioned ways to satisfy their sex drive. Four women (3\%) did nothing about satisfying their sex drive.

When using the FSFI questionnaire it was imperative to explain the nature of the study to the women subjects, to ensure the replies are concerned with experiences and sexual responses over the last 4 weeks and that replies should be sincere and frank and treated as being fully
TABLE 7. Numbers and frequencies of women subjects achieving sex drive satisfaction

\begin{tabular}{|l|c|c|}
\hline Satisfying the sex drive & Numbers & Percentage \\
\hline Not feeling such a need & 10 & 7.5 \\
\hline $\begin{array}{l}\text { Very weak or generally not } \\
\text { feeling such a need }\end{array}$ & 2 & 1.5 \\
\hline $\begin{array}{l}\text { The satisfaction need is } \\
\text { weak }\end{array}$ & 12 & 9.0 \\
\hline $\begin{array}{l}\text { The satisfaction need is } \\
\text { moderate }\end{array}$ & 52 & 39.1 \\
\hline $\begin{array}{l}\text { The satisfaction need is } \\
\text { strong }\end{array}$ & 12 & 11.3 \\
\hline $\begin{array}{l}\text { The satisfaction need } \\
\text { is very strong }\end{array}$ & 15 & 31.6 \\
\hline
\end{tabular}

TABLE 8. Outcomes of the Spearman rank correlation in women subjects

\begin{tabular}{|l|c|}
\hline Variable & Satisfying the sex drive \\
\hline Desire & $0.76^{*}$ \\
\hline Arousal & $0.44^{*}$ \\
\hline Lubrication & $0.39^{*}$ \\
\hline Orgasm & $0.34^{*}$ \\
\hline Satisfaction & $0.28^{*}$ \\
\hline Pain & $0.29^{*}$ \\
\hline Total FSFI & $0.52^{*}$ \\
\hline
\end{tabular}

*Statistical significance; $p<0.05$

confidential. When answering the questions, subjects were asked to keep to the following definitions:

- sexual activity: may include caressing, foreplay, masturbation and vaginal intercourse,

- sexual intercourse: defined as penetration of the vagina by the penis,

- erotic encouragement: includes situations such as foreplay with the partner, self-arousal (masturbation) or erotic fantasies,

- sexual desire or interest: feelings of wanting to have sex, to comply with the partner's sexual preferences and fantasising about having sexual intercourse,

TABLE 9. Table of women's replies to "Fulfilling the satisfaction of the sex drive by"

\begin{tabular}{|l|c|c|c|}
\hline I fulfil the satisfaction of my sex drive by & Number & Percent of replies & Percent of subjects \\
\hline Sexual intercourse with a man & 96 & 55.2 & 72.2 \\
\hline Masturbation & 39 & 22.4 & 29.3 \\
\hline Watching erotic movies, reading erotic books & 12 & 6.9 & 9.0 \\
\hline All of the above to satisfy my sex drive & 23 & 13.2 & 17.3 \\
\hline $\begin{array}{l}\text { I do nothing even though I would very much like to, } \\
\text { but I just can't }\end{array}$ & 4 & 2.3 & 3.0 \\
\hline Total & 174 & 100.0 & 130.8 \\
\hline
\end{tabular}


- sexual arousal: feelings that involve both physical and mental aspects of sexual arousal. This involves feeling warmth and tingling of the genitalia as well as lubrication and muscle contractions [4].

Analysing female sexuality in this study by means of the FSFI questionnaire enables the impact of those selected female characteristics to be assessed on their lives and sexual functioning. Because violent acts disrupt women's sexuality, this study required making an appropriate choice of women subjects to allow women's normal sexuality to be assessed. The present study thus enabled us to determine the effect that stages in women's sexual development has on the extent of their involvement in and ability to engage in sexual activity. The FSFI questionnaire allows one to assess whether/how sexual desire, arousal, lubrication, orgasm, satisfaction or sexually related pain are affected by the following: age, body mass (BMI), height, menarche, taking hormonal drugs, clinical hyperandrogenism and sexual initiation. The study also enables one to assess how the aforementioned factors affect satisfaction of the sex drive. The study outcomes demonstrate that women's sexuality is greater the more women are able to consciously pursue it, which is heavily influenced by cultural factors that define the limits of fulfilling their sexual needs. Thanks to the questionnaire, women can themselves recognise whether they have any problems with their sexuality and assess the quality of their sexuality [5-7].

\section{CONCLUSIONS}

The FSFI questionnaire allows us to gain knowledge about female sexuality and the factors affecting it. The FSFI index (Female Sexual Functioning Index; in Polish IFSK) is an excellent means for screening women for sexual dysfunction.

\section{DISCLOSURE}

Authors report no conflict of interest.

\section{References}

1. Jarząbek-Bielecka G, Pisarska-Krawczyk M, Opala T. Przemoc wobec dzieci, molestowanie seksualne jako problem ginekologii wieku rozwojowego [Violence against children, sexual harassment as a problem of developmental gynecology]. In: Zagadnienia interdyscyplinarne w ginekologii praktycznej [Interdisciplinary issues in practical gynecology]. Pisarska-Krawczyk M, Jarząbek-Bielecka G (eds.). Wydawnictwo Uczelniane Państwowej Wyższej Szkoły Zawodowej im. Prezydenta S. Wojciechowskiego, Kalisz 2014; 157-176.

2. Rekomendacje grupy ekspertów Polskiego Towarzystwa Ginekologicznego dotyczące postępowania w przypadku podejrzenia wykorzystania seksualnego osoby nieletniej opracowane w dniu 16 października 2008 roku [Recommendations from a group of experts of the Polish Gynecological Society for the treatment of suspected sexual exploitation of a minor developed on 16 October 2008].
3. Zoldbrod A. Wszystko, co chcielibyście wiedzieć o swojej seksualności [All you would like to know about your sexuality]. Wydawnictwo Sensus 2010.

4. Wróbel B, Nowosielski K. Female Sexual Function Index (FSFI) Ferguson and R. Rosen 2000. Available from: www.indeks-seksualny-kobiet.pl (accessed: 10 November 2016).

5. Jarząbek-Bielecka G, Wilczak M, Potasińska-Sobkowska A, et al. Overweight, obesity and female sexuality in perimenopause: a preliminary report. Prz Menopauz 2015; 14: 97-104.

6. Miedziejko A, Jarząbek-Bielecka G, Król A, et al. Disorders of pelvic support and urinary incontinence - sexuological aspects. Pol Prz Nauk Zdr 2014; 1: 9-12.

7. Jarząbek-Bielecka G, Wilczak M, Pisarska-Krawczyk M, et al. Wyniki badania seksualnego funkcjonowania kobiet $\mathrm{z}$ zastosowaniem kwestionariusza FSFI z uwzględnieniem BMI. XXXII Kongres Polskiego Towarzystwa Ginekologicznego [Results of the sexual functioning of women using the FSFI questionnaire with BMI included. XXII Congress of the Polish Gynecological Society]. Łódź, 3-5 IX 2015 r.

\section{AUTHORS' CONTRIBUTIONS}

MS, GJB, MPK, prepared the research concept and design the publication. GJB, MPK, APS collected data. MS, MPK, GJB, MW, MM analysed data. MS, GJB, MPK wrote the article. WK finally approved it. 